\title{
1. Requirements for design protection: global commonalities
}

Bernard Volken ${ }^{1}$

While the eye is to be the eye of the Court,
the Court should view the design through the spectacles of the customer.

\section{LAW AND DESIGN}

\section{Design: What's That?}

Design is the form or appearance of a product or parts thereof. ${ }^{3}$ It follows from that distinction between 'design' and 'product' that neither the intended purpose of the product itself nor its underlying idea or concept is covered by design protection. ${ }^{4}$

The economic importance of designs (basically those produced by way of an industrial process $^{5}$ ), and their legal protection, have gained ground over the years, notably in light of prominent conflicts in Europe and abroad such as Crocs v Holey Soles, ${ }^{6}$ Procter \& Gamble

1 Cordial thanks to my appreciated colleague Henning HaRTwig for the precious review and comments regarding the present contribution.

2 Swisstool Manufacturing v Omega Africa Plastics 1975 (4) SA 379 (W).

3 See, for instance, Article 3 lit a Council Regulation (EC) No 6/2002 of 12 December 2001 on Community designs [2002] OJ L 3, 1 ('CDR') ('design means the appearance of the whole or a part of a product resulting from the features of, in particular, the lines, contours, colours, shape, texture and/or materials of the product itself and/or its ornamentation'); see also Article 1 (2) U.K. Registered Designs Act 1949 (c. 88); Section 2 (1) Norwegian Designs Act; Article 1 Swiss Designs Act; Section 1 No 1 German Designs Act; Article 1 (2) Hungarian Design Act; Article 55 (1) Turkey Industrial Property Code; Article 2 (1) Japanese Designs Act.

4 Robert Mirko Stutz/Stephan Beutler/Muriel Künzi, Designgesetz (Stämpfli Verlag AG 2006) 58; similar OLIVER RUHL/JAN TOLKMITT, Gemeinschaftsgeschmacksmusterverordnung (3rd ed. Carl Heymanns Verlag 2019) Article 3, para 6.

5 Interestingly, some jurisdictions understand 'product' as 'any industrial or handicraft item' (see Article 3 lit b CDR) whereas other countries, such as Brazil, focus on a 'model for industrial manufacture' which '(. . .) implies that not every work of purely artistic character will be classified as industrial design' (see MARIstela Basso, Intellectual Property Law in Brazil (Kluwer Law International 2010) 146; see also MurTa Goyanes/Patrícia Rizel, INPI launches the first manual for industrial designs (www.iam-media.com/inpi-launches-first-manual-industrial-designs; accessed 30 July 2020).

6 Crocs v ITC, Appeal No. 2008-1596 (Fed. Cir. 24 February 2010); T-651/16, Crocs v EUIPO/ Gifi Diffusion, ECLI:EU:T:2018:137; Crocs v Liberty Shoes, Delhi High Court, 8 February 2018, CS (COMM) 772/2016; Crocs v Bata India, Delhi High Court, 24 January 2019, FAO (OS) (COMM) 78/2018. 
$v$ Reckitt Benckiser, ${ }^{7}$ Fiat $v$ Great Wall $^{8}$ and Apple v Samsung. ${ }^{9}$ There is apparently a 'link between economic performance and good design', ${ }^{10}$ driving innovative industries to spend considerable amounts on developing new and attractive industrial designs.

\section{Design Law: Balance of Interests?}

Design law affects and reflects the economic interests of different players. These may include the designer ${ }^{11}$ (being either an employee or contractor), the designer's employer or instructing party and any third parties (including users and competitors). The economic interests of these participants may coincide in part, but more often they will conflict.

The designer should be mainly interested in receiving a sufficient financial reward for his creative work. In addition, he might be interested in being cited as the designer. Consequently, some jurisdictions ${ }^{12}$ require that the designer be cited in the design register. ${ }^{13}$ However, such indication does not establish or confer upon the designer any rights to the design registration whatsoever. ${ }^{14}$ At most, he might own the copyright to the design (if and to the extent provided under national law).

The employer or instructing party, as a rule, indemnifies the designer financially. In return, he acquires all rights to the design. The commercial exploitation of these rights is intended to allow the employer or instructing party (being, as a further rule, also the registered right holder) to offset the investments made (remuneration of the designer as well as any costs incurred in obtaining the rights) and, in addition, to market and commercialise

7 Procter \& Gamble v Reckitt Benckiser [2007] EWCA Civ 936, [2008] ECDR 3; Procter \& Gamble v Reckitt Benckiser, Hamburg District Court, 12 July 2006, 308 O 267/06.

8 Fiat Group v Great Wall, Hebei Higher People's Court, [2010] IIC 103 et seq.; Fiat Group v Great Wall, Turin District Court, 14 July 2008, 12146/07, published in: Henning HarTwig (ed.), Design Protection in Europe (Vol. 3, Carl Heymanns Verlag 2009) 197 et seq. with comments from LuCIANo BosotTi, 209 et seq.

9 For instance, Apple v Samsung, 786 F.3d 983 (Fed. Cir. 2015), certiori granted in part, 136 S. Ct. 1453 (2016) and reversed and remanded, 137 S. Ct. 429 (2016); Apple v Samsung, Appeal No. 2013-1129 (Fed. Cir. 18 November 2013); Samsung v Apple [2012] EWCA Civ 1339; Apple v Samsung, Dusseldorf Appeal Court, 31 January 2012, I-20 U 175/11.

10 Susanna Monseau, The Challenges of Protecting Industrial Design in the Global Economy [2012] Texas Intellectual Property Law Journal 495.

${ }_{11}$ This term shall serve as a synonym for creator, author, architect or developer.

12 E.g., Article 9 (1) lit g Swiss Regulation on Design Protection; Section 111 (2) lit b Australian Designs Act.

${ }_{13}$ Under European design law, the citation of the designer is not mandatory (Article 36 [3] lit e CDR) but the designer 'shall have the right, in the same way as the applicant for or the holder of a registered Community design, to be cited as such before the Office and in the register' (Article 18 CDR); see also, for instance, Section 10 German Designs Act.

14 For instance, pursuant to Article 14 (1) CDR, the right to the Community design shall vest in the designer or his successor in title. However, where a design is developed by an employee in the execution of his duties or following the instructions given by his employer, the right to the Community design shall vest in the employer, unless otherwise agreed or specified under national law (Article 14 [3] CDR); see also Section 7 (2) German Designs Act; Section 7 (2) Austrian Designs Act; Article 35 (3) Japanese Designs Act. For details see Anna Tischner, Design Rights and Designer's Rights in the EU (Chapter 5). 


\section{Research handbook on design law}

the design (including licensing or sale). Once the designer has been remunerated, there is usually no further connection between the right holder and the designer. Rather, the right holder will be exclusively entitled and obliged to monitor the market and, if necessary, to enforce the design rights for the purposes of preventing any loss of claims.

The primary interest of third parties (not only but also competitors), finally, is to be as free as possible when using or developing designs and not to infringe the design rights of any third parties (in order, particularly, to avoid paying damages and/or royalties). For this reason, third parties should be interested in design rights which have the smallest possible scope of protection (if any).

\section{Review of Interests}

The different and often conflicting interests of the various players set out above result in the key question of whether a monopoly in a specific design right is justified and desirable, or whether such monopoly would unnecessarily restrict the freedom of designers in developing new designs.

Creativity, innovation and dedication are mandatory and preferable in daily business and economic transactions. It is common ground that these parameters are supported by granting monopoly rights. When and where creativity, innovation and dedication are restricted by such rights, these restrictions must stay within acceptable and, therefore, reasonable limits. Law and practice, in Europe and abroad, seem to have reached this balance of interests by restricting design monopolies in terms of time, ${ }^{15}$ on the one hand, and in terms of the scope of protection of a design right, on the other hand. Indeed, clear standards for assessing the scope of protection of a design and for finding infringement or non-infringement should be in the interest of both right holders and third parties (some jurisdictions allow or require a direct comparison of asserted and accused design while others focus on a test under a so-called short-term recollection). ${ }^{16}$

Overall, these compromises take account of the individual interests of the various participants in as balanced a way as possible and, therefore, should be welcomed; design monopolies which are limited in time and determined in substance deserve to prevail over any concept of 'open design'. ${ }^{17}$

15 Pursuant to Article $12 \mathrm{CDR}$, 'upon registration by the Office, a design which meets the requirements under Section 1 shall be protected by a registered Community design for a period of five years as from the date of the filing of the application. The right holder may have the term of protection renewed for one or more periods of five years each, up to a total term of 25 years from the date of filing.'

16 For details, basically from a European perspective, see CHristoph Gasser, in: Henning Hartwig (ed.), Design Protection in Europe (Vol. 4, Carl Heymanns Verlag 2012) 33 et seq.

17 Particularly, consumers' or users' interest in buying less expensive copies (rather than the original) should not count as a valid argument, leading economic rationale ad absurdum; see, in this context, the question of protecting spare parts; for details see ANNETTE KUR/ÁDÁm GYörGY, Protection of Spare Parts in Design Law: A Comparative Law Analysis (Chapter 10). 


\section{FUNDAMENTAL PRINCIPLES OF DESIGN PROTECTION}

\section{Subject Matter of Design Protection}

On 2 May 2017, the Swiss Federal Supreme Court, in one of its rare cases on design infringement, found that two different premium Swiss-made watches sold under Christophe Claret did not infringe design rights from a Swiss design registered on behalf of Fréderic Jouvenot. ${ }^{18}$ Interestingly, the main feature of the claimed design was an ornament covering the clock face consisting of a flower with 12 petals (instead of an hour hand) (see Figures 1.1-1.4 below).

The Swiss Federal Supreme Court confirmed that when comparing the claimed and the accused designs, one must proceed from the claimed design as registered (not based on the product made according to the design); that is, details not visible in the registration must be ignored. ${ }^{19}$ Additionally, the Court found that, in the case of watches, details matter as the freedom of the designer was limited. ${ }^{20}$ Also, consumers pay particular attention to details because watch companies constantly develop and produce new models; therefore, consumers are used to noting differences in details. ${ }^{21}$ Overall, this case seems to be a perfect example to use in discussing the importance of determining the subject matter of a design in view of anticipated future infringements.

\section{a) Definition of a design}

Any design (whether two- or three-dimensional) consists of features, being arranged by way of, in particular, lines, contours, colours, shape, texture and/or materials. ${ }^{22}$ While these features are inherent in determining a design, the function and size of the design (or the underlying product), as well as whether the design in question has any aesthetic or creative value, are irrelevant. ${ }^{23}$

Furthermore, according to various jurisprudence, protection of a design is not limited to a specific product but, in principle, is open to all possible examples of use. Therefore, the owner of a design which covers the shape of a car, in general, is allowed to challenge use of, say, a soap if the latter's shape produces the same overall impression. This position has been taken and explained in detail in Green Lane v PMS: ${ }^{24}$

18 Jouvenot v Claret, Swiss Federal Supreme Court, 2 May 2017, 4A_565/2016. With respect to the overlap between design and trade mark law see AleXANDER vON MüHLENDAHL, ThreeDimensional Trade Marks and Designs: Comparison and Conflict (Chapter 14); see also HenNING Hartwig, Conflicts between Complex Signs and Designs: Some Observations from the European Watch Industry's Perspective [2014] JIPLP 933 et seq.

19 Jouvenot $v$ Claret (n 18), para 3.2.

20 Ibid., para 3.4.2.

21 Ibid., para 3.4.2. See also HenNing Hartwig, Reciprocity in European Design Law (Chapter 4).

22 See, for instance, Article 3 lit a CDR; Article 1 Swiss Designs Act; Section 1 (1) German Designs Act; Article 1 (2) U.K. Registered Designs Act 1949 (c. 88); Section 2 Norwegian Designs Act; Article 1 (2) Hungarian Design Act; Article 55 (1) Turkey Industrial Property Code; Article 2

(1) Japanese Design Act; Section 2 Canadian Industrial Design Act.

23 See Recital 10 CDR; see also RuhL/Tolkmitt (n 4) Article 3, para 17.

24 Green Lane v PMS International [2008] EWCA Civ 358. 
6 Research handbook on design law

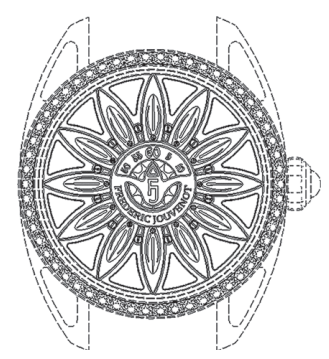

Figure 1.1 Swiss design registration no. 137873 (claimed design, view 1.1)

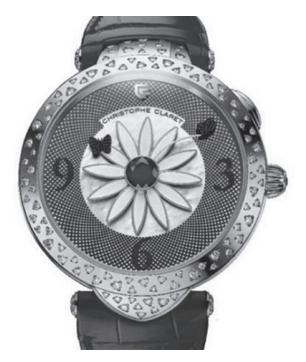

Figure 1.2 Accused design no. 1 (figure taken from Jouvenot v Claret, Swiss Federal Supreme Court, 2 May 2017, 4A_565/2016)

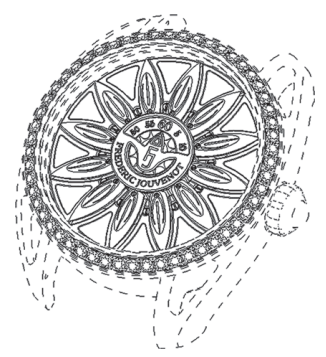

Figure 1.3 Swiss design registration no. 137873 (claimed design, view 1.2)

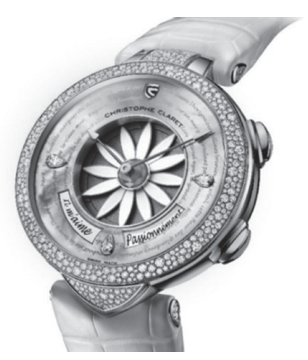

Figure 1.4 Accused design no. 2 (figure taken from Jouvenot v Claret, Swiss Federal Supreme Court, 2 May 2017, 4A_565/2016) 
It is particularly important to realise that the scope of protection covers any use of the design for article, whatever its intended purpose. The scope provision (...) does not limit infringement to 'articles for which the design is registered' or anything like that. So if you register a design for a car you can stop use of the design for a brooch or a cake or a toy, or if you register a textile design you can stop its use on wallpaper, a shirt or a plate.

Pursuant to Article 36 (6) CDR, which served as the starting point in Green Lane v PMS, the (mandatory) 'indication of the products in which the design is intended to be incorporated or to which it is intended to be applied' shall 'not affect the scope of protection of the design as such' (identical provisions can be found, for instance, in the German Designs $\mathrm{Act}^{25}$ ). It is evident that only under this assumption, which has been (and must be) taken by the legislator, will the scope of protection of a design cover any use of the design, including 'using of a product in which the design is incorporated or to which it is applied' (Article 19 [1] Sentence 2 CDR), irrespective of the intended purpose or nature of the underlying product. ${ }^{26}$

Interestingly, where the scope of protection of a design is limited to the nature of the underlying product - such as under the Japanese design law ${ }^{27}$ - it might be assumed that the same design can be registered for different product categories. However, it is held that 'a design that could easily have been created by conversion among different articles based on common commercial usage' is ineligible for design registration under Article 3 (2) Japanese Design Act. ${ }^{28}$

\section{b) Representation of a design}

Any application for registration of a design, as a major prerequisite, must include a 'representation of the design suitable for reproduction' ${ }^{29}$ Both photographs and technical drawings, in particular computer-aided design (CAD) drawings, may be considered ${ }^{30}$ In case of drawings, clear and solid lines should be preferred; unclear lines may risk being rejected. Contours and the three-dimensional character of the design (unless the design, as in the case of graphic symbols and so on, is two-dimensional) must be clearly visible from the figures submitted. ${ }^{31}$ Broken lines are accepted as features for which no protection

25 Section 11 (6) German Designs Act.

26 For details see Henning HaRTwig, Reciprocity in European Design Law (Chapter 4).

27 See Michiko Higuma, in: Alexander Bulling/Angelika Langöhrig/Tillmann Hellwig/ Roland Müller, Designschutz (4th ed. Carl Heymanns Verlag 2018) 176, para 880: 'in order to qualify as a design under the Design Law, the design must pertain to an "article" (other than in case of a partial design, which is discussed below). A shape, a pattern or a color itself, or a combination of pattern and color, does not qualify as a design. For example, a type of font for text alone does not qualify as a design under the Design Law because it is not related to an article.'

28 Ibid., 159 (discussing the conversion of the shape of a motorcycle into the shape of a toy).

29 Article 36 (1) lit c CDR; Article 19 (1) lit a Swiss Designs Act; Ruhl/TolKmitT (n 4) Article 36 para 14. See in detail also Henning Hartwig, 'Mast-Jägermeister' before the Court of Justice of the EU: What the Outcome Really Means (Chapter 12).

30 Article 4 (1) Community Design Implementing Regulation ('CDIR'): 'The representation of the design shall consist in a graphic or photographic reproduction of the design, either in black and white or in colour.' RuHL/Tolkmitt (n 4) Article 36, para 55; STUtz/BeutLer/KünZi (n 4) 516, para 60 .

31 E.g., STUtZ/BeutLER/KüNZI (n 4) 517, para 61. 


\section{Research handbook on design law}

is sought. ${ }^{32}$ In case of photographic representations, the design must be shown against a neutral background. ${ }^{33}$ Each design is to be reproduced without other objects in the background. ${ }^{34}$

Submitting different views of the same design is recommended as, in the case of threedimensional designs, a single view is unlikely to reproduce all characteristic features producing the relevant overall impression (things are different, however, if only one specific view should be protected because, for instance, all other views disclose features which are pre-known). It is also possible that specific details cannot be perceived when using only one figure, which might be relevant when comparing the design with the underlying, real product. $^{35}$

Some jurisdictions may require that the application must contain figures showing the design from all perspectives. ${ }^{36}$ This can lead to difficulties if the application was first filed in a country which is not familiar with such requirements. In this case priority can become critical, making subsequent applications for registration of the design worthless due to lack of novelty. ${ }^{37}$

Finally, according to the German Federal Supreme Court in Writing Utensils, ${ }^{38}$ a design which is registered by way of a black-and-white graphic representation

claims protection for a design, independently of a specific colour scheme. This (. . .) means that, on the one hand, it is possible to assert a broader range of prior art and, on the other hand, the asserted design can also have a broader scope of protection. Accordingly, when assessing infringement, the accused design has to be generalized from its coloured appearance and the question of similarity of the overall impression of the designs must be answered based on a uniform colour scheme.

As a consequence, if a design registered in black and white covers all colours so that its scope of protection is not limited to a particular colour, the holder, by way of reciprocity,

32 See EUIPO, Guidelines for Examination of Registered Community Designs: Examination of Applications for Registered Community Designs (status: 1 February 2020), para 5.3.1; https://guide lines.euipo.europa.eu/binary/1803372/2000000000 (accessed 30 July 2020): 'Broken lines consist of a trace made up of dots or dashes (or a combination of both) and are used to indicate that no protection is sought for the features shown using an interrupted trace. A visual disclaimer consisting of broken lines will usually be combined with continuous lines. (. . .) To be accepted, the features for which protection is not sought should be clearly indicated with broken lines, whereas the parts for which protection is sought should be indicated with continuous lines. In cases where broken lines are a feature of the design (such as stitching on clothing), this must be clear from the representation. In such cases, it may be helpful to file, for example, a magnified view. In cases where broken lines are a feature of the design and a part of the design needs to be disclaimed, any of the other visual disclaimers can be used, such as colour shading, blurring or boundaries.' - Also RuhL/Tolkmiтt (n 4) Article 36, para 79; David Stone, European Union Design Law (2nd ed. Oxford University Press 2016), para 9.24.

33 E.g., STUtZ/Beutler/KüNZI (n 4) 517, para 62.

34 Article 4 (1) lit e CDIR: 'The design shall be reproduced on a neutral background and shall not be retouched with ink or correcting fluid. It shall be of a quality permitting all the details of the matter for which protection is sought to be clearly distinguished and permitting it to be reduced or enlarged.' Ruhl/Tolkmitt (n 4) Article 36, para 23; Stutz/Beutler/KünZi (n 4) 518, para 63.

35 E.g., STUtz/Beutler/KüNZI (n 4) 518, para 64.

36 RuhL/Tolkmitt (n 4) Article 36, para 67.

37 Ibid.; also StUTZ/BeUTLER/KÜNZI (n 4) 519, para 66.

38 Writing Utensils, German Federal Supreme Court, 24 March 2011, I ZR 211/08, para 52. 
must accept that colours of prior designs are likewise ignored. However, it is conceivable that the applicant for registration of the design wishes the design in question to be characterised by a specific colour or combination of colours. In this case, submitting figures of a coloured design makes sense. Otherwise, however, it is advisable to file the design in black and white, so as not to unnecessarily reduce the scope of protection. ${ }^{39}$

In the event of differences between the views of the design as filed and published the figures as submitted are binding for assessing the scope of protection of the design. ${ }^{40}$

\section{c) Interpretation of a design}

In some countries applicants are allowed, within the framework of applying for the registration of a design, to submit figures of several embodiments of the design. For example, the applicant may illustrate the part which, in his opinion, constitutes the main component of the design in isolation, and, in addition, submit alternatives showing the design with one accessory, with two accessories, and so on. Although in these cases multiple embodiments and variants are filed, in each case protection should be limited to only one specific subject matter. It is suggested that this must be identified by the judge (or any other competent authority) by way of interpretation. It is further submitted that the judge must always consider the interest of the public in being able to clearly identify the specific subject matter.

Accordingly, in the Wine Decanter case, the German Federal Supreme Court, as an introductory remark, found that a distinction must be made between the subject matter of a design and its scope of protection. ${ }^{41}$ The subject matter must be taken from the various views of the appearance of the whole or a part of a product resulting from the application as filed ('what you see is what you get'). Neither different nor inconsistent representations of a Community design establish different subject matters; rather, each design application constitutes one subject matter. However, inconsistencies in representing one subject matter require that the Court clarifies the exact identity of such subject matter. This must be done by way of interpretation, including the indication of the product, the description of the design or the classification of the product. ${ }^{42}$ Where the various views of the

\footnotetext{
39 For details see Henning HaRtwig, Reciprocity in European Design Law (Chapter 4).

40 E.g., StUTz/BeutLER/KÜNZI (n 4) 520, para 69. As regards the determination of what design is actually registered see also Utopia Tableware v BBP Marketing [2013] EWHC 3483 (IPEC), paras 87 et seq.; Rolling Mat, Aargau Commercial Court, 5 March 2014, HOR.2012.23 [at 6.1.2 and 6.1.3].

${ }_{41}$ Wine Decanter, German Federal Supreme Court, 8 March 2012, I ZR 124/10, para 12; cf. also comments by Henning HaRTwig, The German Supreme Court on multiple representations [2013] MIP (Europe IP Focus) 46. See also Procter \& Gamble v Reckitt Benckiser [2006] EWHC $3154(\mathrm{Ch})$, para 48: 'the registration holder is entitled to choose the level of generality at which his design is to be considered. If he chooses too general a level, his design may be invalidated by prior art. If he chooses too specific a level he may not be protected against similar designs. But in my judgment to allow features that are not the subject-matter of the registration to play a part in the assessment of the overall impression would unduly restrict the scope of protection.'

${ }^{42}$ Wine Decanter (n 41), paras 24 et seq. Interestingly, in William O'Connell v Robert Scanlon, the Controller of the Irish Patent Office, on 3 March 2015, found (para 14) that he 'cannot attach any relevance to the description of the design as supplied by the Proprietor when he lodged his application (...) because, oftentimes, the description of a design can be at variance with the representations provided by an applicant for registration. However, this is not the case in these proceedings as the
} 
registered design were inconsistent, that is, they showed a base in one representation but not in another, the Court found it appropriate to limit the specific subject matter to the greatest common subset, that is, to include those features that can be seen from all the different views. ${ }^{43}$

Turning from infringement standards to validity issues, it is interesting to look at the Vehicles (Toys) case (decided by EUIPO's Board of Appeal), where the validity of a Community design showing multiple figures of a toy car with a trailer was challenged based on an identical toy car without a trailer. The Board of Appeal found ${ }^{44}$ that even though

the trailer has thus become an element of the design of the toy vehicle, it is a relatively marginal one, in the sense that the toy vehicle - with or without the trailer - produces on the informed user the same overall impression. The informed user will perceive the trailer for what it clearly is: an accessory. The accessory character of the trailer is well demonstrated by the fact that it is not a fixed element but one that can be easily separated from the main product. The trailer is, in fact, an optional accessory - i.e. something that anybody playing with the toy may decide to use or not - and may hardly be qualified as 'a significant part of the design'.

The alternative reasoning, according to the Board, would appear 'to lend legitimacy to the integral reproduction of an existing design, with the sole proviso that some other component customarily used in combination with the product in question be added, for example a rim provided with a tyre'. ${ }^{45}$

\section{Priority Claim ('The Same')}

Design protection, in general, is limited to the territory of the individual design registration. However, as the publication of a design registration amounts to novelty-destroying prior art, subsequent filings in other jurisdictions would become impossible (given that worldwide disclosure of prior art is relevant under many national design laws). To relieve designers and applicants of undue pressure and the need to file design applications simul-

representations of the design are in line with the description.' (www.ipoi.gov.ie/en/law-practice/ written-grounds/industrial-designs-act-2001/decision-in-hearing-re-design-21726-a-peaked-hat-.pdf; accessed 30 July 2020).

43 Ibid, , para 31. In Sports Helmet, German Federal Supreme Court, 20 December 2018, I ZB 25/18, the Court found (Official headnotes): 'Where several views of a design filed by way of a single application show different embodiments of a product (here: sports helmet) with different features of the appearance of this product (here: different strap, with or without tab, different colors, color contrasts, decors), these views do not visibly reproduce the appearance of the whole of "a" product. In such a case, the design does not disclose a unitary subject matter, in the sense of Section 1 No. 1 German Designs Act, and, therefore, is invalid pursuant to Section 33 (1) No. 1 German Designs Act. Where the design holder claims design protection for the deviating features, it is not permissible to determine a unitary subject matter based on the intersection of the features common to all views.' Albeit, in a formal sense, the new practice is limited to the construction of Section 1 No. 1 German Designs Act the identical provision under European design law, which is Article 3 lit a Community Designs Regulation, will be impacted as well. For details see HenNing HaRTwig, Reciprocity in European Design Law (Chapter 4).

44 Vehicles (toys), EUIPO (Board of Appeal), 12 July 2011, 1701/2010-3, para 27.

45 Ibid. 
taneously all over the world, efforts were made early on at international level to establish a 'priority right'.

As a consequence, Article 4 A (1) and (2) Paris Convention already contained such a provision, pursuant to which

any person who has duly filed an application for (. .) an industrial design (...) in one of the countries of the Union, or his successor in title, shall enjoy, for the purpose of filing in the other countries, a right of priority during the periods hereinafter fixed. Any filing that is equivalent to a regular national filing under the domestic legislation of any country of the Union or under bilateral or multilateral treaties concluded between countries of the Union shall be recognized as giving rise to the right of priority.

The period of priority is six months for industrial designs, starting from the date of filing of the first application, pursuant to Article $4 \mathrm{C}$ (1) and (2) Paris Convention. This right of priority also applies, in accordance with Article 2 (1), 3 (1) TRIPS Agreement, to Member States of the WTO which have not ratified the Paris Convention.

The main prerequisite for claiming a right of priority is a regular national filing of the application in the first country. 'Regular national filing' means any filing that is adequate to establish the date on which the application was filed in the country concerned, whatever the subsequent fate of the application (Article 4 A [3] Paris Convention) may be; that is, irrespective of whether the first application giving rise to the priority is withdrawn, abandoned or refused. ${ }^{46}$

The right of priority must be exercised within six months starting from the date of filing of the first application. The filing of subsequent applications must, in principle, concern the 'same subject' (see Article 4 C [4] Paris Convention) as the first application giving rise to the right of priority. If the same subject is filed but different figures are used, priority is properly being claimed if such differences are required by national law. ${ }^{47}$

A claim of priority does not necessarily have to be based on an application for registration of a design. Rather, it can also be based, largely depending on individual national requirements, on other applications for IP rights such as, for instance, applications for utility patents, utility models and three-dimensional trade marks. ${ }^{48}$

\section{Test for Validity}

Common, globally valid requirements for protection of industrial designs are provided in Article 25 (1) TRIPS Agreement, establishing, however, only minimum standards: 'Members shall provide for the protection of independently created industrial designs that are new or original. Members may provide that designs are not new or original if they do not significantly differ from known designs or combinations of known design features.'

Member States are therefore only obliged to provide protection of a design if the specific design was unknown to the designer and, thus, independently created. This requirement of subjectivity is completed by the (objective) requirement of novelty or originality.

\footnotetext{
46 Ruhl/Tolkmitt (n 4) Article 41, para 7; Stutz/Beutler/KünZi (n 4) 562, para 14.

47 StUtz/BeUtler/KüNZI (n 4) 564, para 18.

48 For details, basically from a European perspective, see Henning HarTwig, Claiming Priority under the Community Design Scheme (Chapter 8).
} 
However, due to the wording of Article 25 (1) TRIPS Agreement, some authors doubt whether both requirements must be met cumulatively in order to establish protection. ${ }^{49}$

Where design protection - in terms of protection of a specific shape - is not limited to the intended purpose of the underlying product or a particular dimension of the design, all prior designs are, in principle, to be considered as a relevant subject of comparison for testing the validity of a design, irrespective of what purpose the prior design was or is intended to serve. ${ }^{50}$ When comparing prior art and the challenged later design, all visible features which influence the overall impression of the prior art must be considered. ${ }^{51}$

As a final remark, the majority of national design offices do not examine the validity of a design ${ }^{52}$ but check only formal requirements (such as payment of registration fees and so on), thus facilitating an inexpensive and quick registration process. ${ }^{53}$ Where and once validity of a design, according to the different national schemes, is tested, this must be done under the criteria of novelty, individual character and/or non-obviousness.

\section{a) Novelty}

Pursuant to Article 25 (1) TRIPS Agreement, Members shall 'provide for the protection of independently created industrial designs that are new or original'. While the requirement establishes mandatory minimum standards, Members may 'provide that designs are not new or original if they do not significantly differ from known designs or combinations of known design features'.

It follows from that provision (also in the absence of any further substantive harmonisation of international design law) that (i) 'novelty' and 'originality' should be interpreted as synonyms ${ }^{54}$ (although in some jurisdictions, such as the United States, both terms are different) and (ii) identity between the design at hand and the prior art (either a specific prior design or a combination of features known from various prior designs) is not required to render a design invalid (rather, 'significant differences' between the conflict-

49 Agree (in the sense of accumulation): Alessandro L. Celli/Roger Staub, Designrecht (Schulthess 2003) Article 2, para 20; Stutz/Beutler/KünZI (n 4) 107, para 35; Peter Heinrich, Designgesetz (Navigator 2014) Article 2, paras 195 et seq. Disagree: AnnetTe Kur, Die Zukunft des Designschutzes in Europa [1998] GRUR Int. 356, note 22; Pataky Tibor Samuel, TRIPS und Designschutz [1995] GRUR Int. 653; for more details, see JAN Busche/Peter-TobIas STOLL/ ANDREAS WieBe, TRIPS, Internationales und europäisches Recht des geistigen Eigentums (Carl Heymanns Verlag 2013) Article 25, paras 10 et seq.

50 Markus Wang, Designrecht in: Schweizerisches Immaterialgüter- und Wettbewerbsrecht (SIWR) VI (Helbing Lichtenhahn Verlag 2007) 107.

51 Stutz/BeutleR/KüNZI (n 4) 111, para 43.

52 Interestingly, for instance, the Hungarian Intellectual Property Office carries out a novelty search pursuant to Article 44 Hungarian Design Act; $c f$. www.sztnh.gov.hu/en/English/jogforras/ Design_Act_XLVIII_2001_EN.pdf (accessed 30 July 2020).

53 See, for instance, Article 21 Swiss Design Act; Article 3 U.K. Registered Designs Act 1949 (c. 88); Section 39 German Designs Act; Article 45 CDR; Chapter 4, Part 3, Division 1 Australien Design Act. In contrast to solely formal examination, China is also examining obvious substantive defects (new Guidelines Part I, Chapter 3 Section 1 Chinese Design Act). Other countries also provide for both formal and substantive examination; $c f$., for instance, Chapter 1500 of the Manual Of Patent Examining Procedure of the United States; Section 5 and 6 Canadian Industrial Design Act; Article 17 Japanese Designs Act; Section 15 South African Designs Act.

54 Busche/Stoll/Wiebe (n 49) Article 25, para 8. 
ing designs are allowed to be required in order to find novelty or originality). While this standard is not mandatory, some jurisdictions have adopted it for finding novelty (others have established a two-step test, assessing novelty in a narrower sense to be followed by a more general test). This said, novelty-destroying prior art appears to range from identical designs and quasi-identical prior art to those designs which do not 'significantly differ' from the specific design at hand.

More precisely, and according to Article 6 (1) Canadian Industrial Design Act, for instance, a design is registered if 'it is not identical with or does not so closely resemble any other design already registered as to be confounded therewith'. ${ }^{55}$

Pursuant to Article 4 Indian Designs Act, a 'design which is not new or original (. . .) or is not significantly distinguishable from known designs or combination of known designs (. . .) shall not be registered' ${ }^{56}$ Consequently, novelty or originality of a design is narrower than 'significantly distinguishable'.

According to Section 5 (2) New Zealand Designs Act,

a design shall not be registered thereunder unless it is new or original and in particular shall not be so registered in respect of any article if it is the same as a design which before the date of the application for registration has been registered or published in New Zealand in respect of the same or any other article or differs from such a design only in immaterial details or in features which are variants commonly used in the trade. ${ }^{57}$

Interestingly, while this provision adds to the wording of Article 25 (1) TRIPS Agreement ('new or original') the notion of 'immaterial details' also to be found in European design law, the event of disclosure is linked to the territory of New Zealand, establishing a 'local novelty' requirement. ${ }^{58}$

Pursuant to Section 15 (1) Australian Designs Act, a design is registrable if it is new and distinctive when compared with the prior art base for the design as it existed before the priority date of the design. Pursuant to Section 16 (1) Australian Designs Act, a 'design is new unless it is identical to a design that forms part of the prior art base for the design. A design is distinctive unless it is substantially similar in overall impression to a design that forms part of the prior art base for the design.' Pursuant to Section 19 (1) Australian Designs Act, 'whether a design is substantially similar in overall impression to another design, the person making the decision is to give more weight to similarities between the designs than to differences between them'. 59

Pursuant to Section 5 (1) and (2) Singapore Registered Designs Act,

a design which is new may (...) be registered in respect of an article specified in the application. A design for which an application for registration is made shall not be regarded as new if it is the same as a design registered in respect of the same or any other article in pursuance of a prior application; or published in Singapore or elsewhere in respect of the same or any other

55 www.wipo.int/wipolex/en/text.jsp?file_id=207414 (accessed 30 July 2020).

56 www.wipo.int/wipolex/en/text.jsp?file_id=128104 (accessed 30 July 2020).

57 www.wipo.int/wipolex/en/text.jsp?file_id=335744 (accessed 30 July 2020).

58 Michael Hawkins, The death knell? [2005/2006] Patent World (December/January) 12.

59 www.wipo.int/wipolex/en/text.jsp?file_id=290376 (accessed 30 July 2020). 


\section{Research handbook on design law}

article before the date of the first-mentioned application, or if it differs from such a design only in immaterial details or in features which are variants commonly used in the trade. ${ }^{60}$

According to Article 23 (2) Patent Law of the People's Republic of China, 'designs for which the patent right is to be granted shall be ones which are distinctly different from the existing designs or the combinations of the features of existing designs', the notion 'distinctly different' arguably being close to 'significantly distinguishable' under Chinese design law. ${ }^{61}$

According to Article 3 (1) Japanese Designs Act, a

creator of a design that is industrially applicable may be entitled to obtain a design registration for the design, except for the following: (i) designs that were publicly known in Japan or a foreign country, prior to the filing of the application for design registration; (ii) designs that were described in a distributed publication, or designs that were made publicly available through an electric telecommunication line in Japan or a foreign country, prior to the filing of the application for design registration; or (iii) designs similar to those prescribed in the preceding two items. ${ }^{62}$

In accordance with Section 14 (1) and (2) South African Designs Act, the

proprietor of a design which in the case of an aesthetic design is new and original (or) in the case of a functional design is new and not commonplace in the art in question may (. . .) apply for the registration of such design. A design shall be deemed to be new if it is different from or if it does not form part of the state of the art immediately before the date of application for registration thereof or the release date thereof, whichever is the earlier. ${ }^{63}$

According to Title 35 U.S.C. Section 171, whoever 'invents any new, original and ornamental design for an article of manufacture may obtain a patent therefor, subject to the conditions and requirements of this title. The provisions of this title relating to patents for inventions shall apply to patents for designs, except as otherwise provided'. ${ }^{64}$

The key date for assessing novelty is the date of filing of the application for registration or the date of priority. This appears to be common ground according to the law of numerous national jurisdictions. ${ }^{65}$ It also seems to be widely accepted that disclosure of relevant prior art is not limited to the territory of the design whose novelty is challenged; rather, novelty, in principle, must be assessed worldwide. ${ }^{66}$ Nonetheless, however, disclosure of prior art is not relevant and shall be disregarded if the underlying event of disclosure,

60 www.wipo.int/wipolex/en/text.jsp?file_id=174498 (accessed 30 July 2020).

61 www.wipo.int/wipolex/en/text.jsp?file_id=178664 (accessed 30 July 2020). For details see Ling Yu/WeIKe Du, From 'Dissimilarity' to 'Significant Difference' - Recent Developments and Challenges in the Requirements for Design Patents in China [2014] IIC 500 et seq.

62 www.wipo.int/wipolex/en/text.jsp?file_id=299616 (accessed 30 July 2020).

63 www.wipo.int/wipolex/en/text.jsp?file_id=293352 (accessed 30 July 2020).

64 www.wipo.int/wipolex/en/text.jsp?file_id=130047 (accessed 30 July 2020).

65 See, for instance, Article 5 (1) lit b CDR; Section 2 (2) German Designs Act; Section 2 Austrian Designs Act; Article 2 Swedish Design Protection Act; Section 3 Norwegian Designs Act; Article 3 (1) (i) Japanese Designs Act; Section 14 (2) South African Designs Act; Section 5 (2) Hong Kong's Registered Designs Ordinance.

66 Ruhl/Tolkmitt (n 4) Article 7, para 8. 
in the words of Community design law (Article 7 [1] CDR), 'could not reasonably have become known in the normal course of business to the circles specialised in the sector concerned, operating within the Community'. ${ }^{67}$ Similar provisions and/or precedents can be found in various other countries. ${ }^{68}$ Consequently, identification of the relevant target group at hand is essential and might differ depending on the specific design sector at hand. Novelty must be examined objectively; consequently, actual knowledge of the target group is not relevant, only the hypothetical possibility of knowledge of the existing design corpus. Accordingly, this can result in parallel - or double - creations which are eligible for protection independently of one another, provided that the design created first was disclosed in a manner which could not have become known to the relevant target group. ${ }^{69}$

\section{b) Individual character}

Some jurisdictions, basically in the European Union and/or Europe, established the criterion of 'individual character' as a second test in order to assess whether a design is valid. Although such a test is not required under Article 25 (1) TRIPS Agreement (where the test is novelty or originality), the individual character test is widely accepted as being in line with international design law. ${ }^{70}$

To start with Community design law, according to Article 6 (1) CDR, a 'design shall be considered to have individual character if the overall impression it produces on the informed user differs from the overall impression produced on such a user by any design which has been made available to the public' before the date of filing or priority. Pursuant to Article 6 (2) CDR, in 'assessing individual character, the degree of freedom of the designer in developing the design shall be taken into consideration'. Identical provisions can be found in the national design laws in the 27 Member States of the European Union being harmonised on the grounds of the corresponding Article 5 Designs Directive.

Other European countries which are not (yet) Member States of the EU have established identical or at least similar standards for testing individual character of a design. Section 3 (3) Norwegian Designs Act, for instance, is identical to Article 6 CDR.${ }^{71}$ Slightly different from that, Article 2 (3) Swiss Designs Act provides that a 'design does not have individual character if its overall impression differs only in immaterial features from a design which could have been known to the relevant public operating within Switzerland'. ${ }^{2}$

Outside of Europe, the notion or test of individual character is rather unknown. Interestingly, although the Singapore Registered Design Act does not explicitly require

67 Following the Court of Justice of the European Union, Joined Cases C-361/15 P and C-405/15 P, Easy Sanitary v EUIPO/Group Nivelles, ECLI:EU:C:2017:720, paras 126 et seq., the concept of an informed user cannot be interpreted as meaning that it is only if that user knows the earlier design that the earlier design could prevent recognition of the individual character of a subsequent design; for details see Henning HaRTwig, Relevanter Formenschatz im Gemeinschaftsgeschmacksmusterrecht [2017] GRUR 1212 et seq.

68 For details see, for instance, Article 2 (2) Swiss Designs Act; Article 3 (2) Japanese Designs Act; Section 5 (1) Norwegian Designs Act; Article 2 Swedish Designs Protection Act.

69 Stutz/Beutler/KüNZi (n 4) 114, para 53.

70 See, for instance, RuHL/TolkmitT (n 4) Article 4, para 6.

71 https://wipolex.wipo.int/en/text/517265 (accessed 30 July 2020).

$72 \mathrm{https} / / /$ wipolex.wipo.int/en/text/508507 (accessed 30 July 2020). 
a design to have individual character, ${ }^{73}$ courts require 'some perceptible appearance of individual character'. ${ }^{74}$

In the absence of any global harmonisation of substantive requirements for finding individual character of a design, key elements of this process have been identified and/or clarified on a national scale only (if any at all). For example, the notion of the informed user is central when discussing the individual character of a design. Will such a user compare two designs one-to-one or is the user's imperfect recollection relevant? ? $^{75}$ Is it permitted to compare also the underlying product of a design registration (where available) or should any comparison (direct or not) be limited to the views and figures as submitted ${ }^{76}$ How is the degree of freedom of the designer to be assessed - do technical, statutory and aesthetic constraints count likewise? ${ }^{77}$

\section{c) Non-obviousness}

By way of exception from the scheme discussed above (novelty plus individual character), some countries established a specific standard requiring a certain degree of linkage between the individual design at hand and the relevant prior art in order to find validity.

Pursuant to Title 35 U.S.C. Section 171 Sentence 2, the provisions 'relating to patents for inventions shall apply to patents for designs'. This implies that a patentable design must be non-obvious under Title 35 U.S.C. Section 103. Consequently, a design patent

may not be obtained (. . .) if the differences between the claimed invention and the prior art are such that the claimed invention as a whole would have been obvious before the effective filing date of the claimed invention to a person having ordinary skill in the art to which the claimed invention pertains. ${ }^{78}$

\section{Interestingly, Article 3 (2) Japanese Design Act provides that}

where, prior to the filing of the application for design registration, a person ordinarily skilled in the art of the design would have been able to easily create the design based on shape, patterns or colors, or any combination thereof that were publicly known in Japan or a foreign country, a design registration shall not be granted for such a design (except for designs prescribed in any of the items of the preceding paragraph), notwithstanding the preceding paragraph. ${ }^{79}$

\footnotetext{
73 https://wipolex.wipo.int/en/text/174498 (accessed 30 July 2020).

74 George WeI, Industrial Design Law in Singapore (Academy Publishing 2012) 78, para 2.44.

75 C-281/10 P, PepsiCo v EUIPO/Grupo Promer, ECLI:EU:C:2011:679, para 55; C-101/11 P and C-102/11 P, Herbert Neuman v EUIPO/José Manuel Baena, ECLI:EU:C:2012:641, para 57; see also Henning Hartwig, Case Comment on Herbert Neuman v EUIPO/José Manuel Baena [2013] IIC 248.

76 T-666/11, Budziewska v EUIPO/Puma, ECLI:EU:T:2013:584, para 30.

77 T-9/07, Grupo Promer v EUIPO/PepsiCo, ECLI:EU:T:2010:96, para 67; joined Cases T-83/11 and T-84/11, Antrax v EUIPO/THC, ECLI:EU:T:2012:592, para 81.

78 For details see MAUREEN LONG, The nonobviousness requirement for design patents [2017] AIPLA Quarterly Journal 193 et seq. - For subtle differences between the 'substantially similar' standard for anticipation and the 'basically the same' standard for obviousness see Man Wah v Raffel, Patent Trial and Appeal Board (USPTO), PGR2019-00029 (see https://secureservercdn.net/184. 168.47.225/9ac.02d.myftpupload.com/wp-content/uploads/2019/07/PTAB-PGR2019-00029-9-1.pdf; accessed 30 July 2020).

79 www.cas.go.jp/jp/seisaku/hourei/data/DACT.pdf (accessed 30 July 2020).
} 
Such a test appears to be similar to the non-obviousness test required under U.S. design patent law.

\section{Test for Infringement}

Under European design law, the scope of the protection conferred by a Community design (registered or not) shall include any design which does not produce a different overall impression in the informed user. In assessing the scope of protection, the degree of freedom of the designer in developing his design shall be taken into consideration (Article 10 CDR). While identical or highly similar provisions can be found in the 27 Member States and other European countries, such as Norway ${ }^{80}$ and Switzerland, ${ }^{81}$ Article 11 (1) Canadian Industrial Design Act, for instance, provides that

during the existence of an exclusive right, no person shall, without the licence of the proprietor of the design, make, import for the purpose of trade or business, or sell, rent, or offer or expose for sale or rent, any article in respect of which the design is registered and to which the design or a design not differing substantially therefrom has been applied.

Furthermore, in considering whether differences are substantial, the extent to which the registered design differs from any previously published design may be taken into account (Article 11 [2] Canadian Industrial Design Act).

As part of such exercise in order to assess infringement of a design right, the relevant audience involved must be identified. Some design laws also require the parties to identify characteristic or dominant features of the conflicting designs and, based on that finding, the (corresponding or different) overall impression. Another important criterion in assessing scope of protection and infringement of a design relates to the degree of departure of the asserted design from the relevant prior art, including aesthetic, technical and/or statutory constraints the designer had to overcome when developing the asserted design (degree of freedom).

\section{Exclusion from Protection}

Pursuant to Article 25 (1) Sentence 3 TRIPS Agreement, Members may provide that design protection 'shall not extend to designs dictated essentially by technical or functional considerations'. ${ }^{82}$

While this ground for exclusion is not mandatory, corresponding standards can be

80 Section 9 (2) Norwegian Designs Act: 'The design right shall apply to any design that does not produce on an informed user a different overall impression. In assessing the scope of the design right, the degree of freedom of the designer in developing the design shall be taken into consideration.'

81 Article 8 Swiss Designs Act: 'The scope of protection of a design right shall include all designs having the same characterizing features and, therefore, producing the same overall impression as a registered design.'

82 For details see JASON J. Du Mont/Mark JANIS, Trends in Functionality Jurisprudence: U.S. and E.U. Design Law (Chapter 2); further PERRY J. SAIDMAN, The demise of the functionality doctrine in design patent law [2017] Notre Dame Law Review 1471; ToBIAs Endrich, Pinning down 
found in various jurisdictions, such as Article 8 (1) CDR, Article 7 (1) Designs Directive, Article 4 lit c Swiss Designs Act, Article 58 (4) Turkey Industrial Property Code, Article 5 Japanese Designs Act, Article 14 (5) lit a South African Designs Act and Title 35 U.S.C. Section 171 ('ornamental' ${ }^{83}$ ). Whether such an exception must be construed narrowly; 84 whether and to what extent the designer's freedom in developing the design must be considered; and, in particular, whether a proven multiplicity of forms is sufficient to deny the exclusion ${ }^{85}$ - in Europe ${ }^{86}$ and abroad ${ }^{87}$ these questions are widely and controversially discussed, alongside others, including whether if only a part or feature of the design is technically dictated the latter is nevertheless eligible for protection, provided that the remaining part of the design meets the requirements for protection. ${ }^{88}$

functionality in EU design law [2019] JIPLP 156; UMA SUTHERSANEN, Excluding designs (and shape marks): where is the EU Court of Justice Going? [2019] IIC 157.

83 See Jason J. Du Mont/Mark Janis, Functionality in Design Protection Systems [2012] J. Intell. Prop. L. 264: 'In most modern design patent cases, courts invoke the ornamentality requirement but analyze the issue by referring to non-functionality, treating it as the converse of ornamentality.' For example, in Norco v Mecca, 617 F. Supp. 1079, 1080, 227 USPQ 724, 725 (D. Conn. 1985), the court held that a 'primarily functional invention is not patentable' as a design. For more details see Automotive Body Parts Association v Ford, No. 18-1613 (Fed. Cir. 2019); Chapter 1504.01 (c) Manual Of Patent Examining Procedure of the United States; available at www.uspto. gov/web/offices/pac/mpep/ (accessed 30 July 2020).

84 Landor \& Hawa v Azure [2006] EWCA Civ 1285, para 38.

85 Foam Module, Dusseldorf District Court, 16 July 2008, 14c O 179/07; Car Wheels, Dusseldorf District Court, 28 November 2013, 14c O 304/12; Rolling Mat, Aargau Commercial Court, 5 March 2014, HOR.2012.23 [at 6.3.2].

86 See, recently, C-395/16, DOCERAM v CeramTec, ECLI:EU:C:2018:172, para 39, finding as follows: 'Article 8 (1) CDR must be interpreted as meaning that in order to determine whether the features of appearance of a product are exclusively dictated by its technical function, it must be established that the technical function is the only factor which determined those features, the existence of alternative designs not being decisive in that regard (. . .) Article 8 (1) CDR must be interpreted as meaning that, in order to determine whether the relevant features of appearance of a product are solely dictated by its technical function, within the meaning of that provision, the national court must take account of all the objective circumstances relevant to each individual case. In that regard, there is no need to base those findings on the perception of an "objective observer".'

87 For instance, in Zero Spill v Heide (2015 FCA 115), the Canadian Federal Court of Appeal clarified that a functional feature of an industrial design may be protected under the Industrial Design Act. However, although there were many similarities between the claimed and the accused design, the Federal Court denied infringement on a balance of probabilities because, inter alia, the plaintiff failed to address the 'legal distinction between design features that are visually appealing and those that are purely functional or utilitarian'. See also Travel Blue v Siddhivinayak Enterprises, Bombay High Court, 25 March 2019, COMIP (L) 358 OF 2019, finding that where 'the Plaintiff has obtained a registration for the "shape and configuration" of the design as a whole, (. . .) for a defense of "functionality" to succeed, the Defendant is required to show that a "function" can be performed by that shape and/or form and/or design alone. If the same "function" can be performed by different shapes, it is not sufficient for the Defendant to merely show that the design/shape in question performs a function as well' (para 29). For a detailed country-chapter approach see Christopher V. Carani, Design Rights - Functionality and Scope of Protection (Wolters Kluwer 2017), passim. With respect to the protectability of trade dress under U.S. law and the issue of functionality see Bodum v A Top New Casting, No. 18-3020 (7th Cir., 12 June 2019).

88 For details see Du Mont/Janis (n 83) passim; David Wilkinson, Case closed: Functional designs protected by design right [2007] EIPR 118. 
Apart from that major ground for exclusion from design protection (and other grounds such as lack of validity or absence of design ${ }^{89}$ ), some jurisdictions provide that a design right 'shall not subsist in a design which is contrary to public policy or to accepted principles of morality' (Article 9 CDR). These scenarios may include, for example, racially or sexually offensive representations; the specific assessment should be based on the perception of the respective individual country. ${ }^{90}$

\section{Defences to Infringement}

As with established practice under, for instance, international patent and copyright law, there are various defences available against the asserted infringement of a design right. General defences in the field of IP include exhaustion, prior rights, private use or prescription and acquiescence. In addition, increasing relevance is given to more specific defences available in the two most important regimes used to protect product configurations - trade marks and designs - as well as extraneous defences (such as those under the constitutional right of the freedom of expression). ${ }^{91}$

\section{REGISTRATION VERSUS USE}

\section{Concept of Registration}

In many jurisdictions, such as, for example, Canada, China, Germany, Japan, Switzerland or the United States, design protection can only be established, without any exception, via application for registration in the design register. Accordingly, product shapes which are used on the market but have not been registered do not enjoy any design protection. Instead, in such cases, one needs to resort to copyright and/or unfair competition law (provided that these rights are available and effective in the specific case).

\section{Concept of Use}

In addition to the established concept of registration, some jurisdictions, ${ }^{92}$ particularly the European Union and the United Kingdom, allow protection of unregistered design

89 Under some design laws, physical configurations such as flowcharts, chemical and mathematical formulas, rules of the games, concepts or sheet music do not fall under the definition of a 'design' and, therefore, are not protected under design law.

90 Stutz/Beutler/Künzi (n 4) 193, para 74. See also Schupp v IGE, Swiss Federal Administrative Court, decision of 26 February 2016, B-4975/2013, finding that Swiss Design No. 2011-00718, showing a pendant with a Christian cross, a Star of David and a crescent symbol would not be suitable for insulting religious feelings of believers.

91 For details see Natalia KaPYRINA, Limitations in the Field of Designs [2018] IIC 41 et seq.

92 Interestingly, Turkey amended its Intellectual Property Code as of January 10, 2017 to recognise unregistered design rights when first introduced in Turkey, with a term of protection of three years from first public disclosure (comparable to the EU); see SALIH POLATER, Designschutz nach dem neuen türkischen Gesetz zum gewerblichen Rechtsschutz [2017] GRUR Int. 1030 et seq.; CAHIT SuluK, Basics of the new Turkish Industrial Property Law [2018] JIPLP 492, 498 et seq. 
rights - which, however, basically provides protection only against copying. ${ }^{93}$ Also, the prospect of showing authorship and ownership of unregistered design rights can prove to be daunting for right holders. ${ }^{94}$

\section{Similarities and Differences}

When comparing registered and unregistered design rights provided under the various national jurisdictions, there seem to exist some similarities, but even more differences. In fact, while, particularly from a European perspective, the requirements for protection are identical (novelty and individual character), registered and unregistered designs significantly differ in their term of protection - 25 years maximum in the case of registered designs (Article $12 \mathrm{CDR}$ ), but only three years in the case of unregistered designs (Article 11 CDR).

Differences also exist in that a registered design right automatically comes into existence upon registration by the Office, while in the European Union a design shall be protected by an unregistered Community design right only if the design was first made available to the public within the Community (Article 11 [1] CDR), that is, within the territory of the Community (Article 110a [5] CDR).

Finally, whereas the 'scope of the protection conferred by a Community design shall include any design which does not produce on the informed user a different overall impression' (Article 10 [1] CDR), Article 19 (2) Sentence 1 CDR clarifies that an unregistered Community design shall prevent third parties' acts 'only if the contested use results from copying the protected design'. Unlike in registered Community design rights, the contested use shall not be deemed to result from copying an unregistered Community design 'if it results from an independent work of creation by a designer who may be reasonably thought not to be familiar with the design made available to the public by the holder' (Article 19 [2] Sentence 2 CDR).

\section{DESIGN VERSUS PATENT VERSUS COPYRIGHT APPROACH}

\section{Patent Approach}

Unlike, for instance, European design law, the U.S. approach does not consider design law as a field of law sui generis but rather as a part of utility patent law. ${ }^{95}$ This is (pars pro toto) demonstrated by the fact that the requirements for protection of a design patent strongly recall those of a utility patent. In fact, according to Title 35 U.S.C. Section 171, whoever 'invents any new, original and ornamental design for an article of manufacture may obtain a patent therefor, subject to the conditions and requirements of this Title. The

\footnotetext{
93 For details see Estelle Derclaye, Protection of Designs on the Basis of Use (Chapter 7).

94 For details see AnNa Tischner, Design Rights and Designer's Rights in the EU (Chapter 5).

95 For details see Margaret Polson, Enablement and Indefiniteness in U.S. Design Patents after In re Maatita and Ex parte Kaufman (Chapter 6).
} 
provisions of this title relating to patents for inventions shall apply to patents for designs, except as otherwise provided'. ${ }^{96}$

Consequently, in addition to the 'novelty' and 'originality' requirements, which are also established in European design law in a similar form ('novelty' and 'individual character'), 'non-obviousness' constitutes a further requirement for protecting a U.S. design patent. ${ }^{97}$ According to Section 35 United States Code $\S 103$ (a),

a patent may not be obtained (...) if the differences between the subject matter sought to be patented and the prior art are such that the subject matter as a whole would have been obvious at the time the invention was made to a person having ordinary skill in the art to which said subject matter pertains.

As a result of the U.S. patent approach, it seems, on the one hand, as if the designer must overcome a larger number of hurdles, compared with European design law, in order to obtain design protection. However, on the other hand, it appears that once design protection has been granted, the U.S. design patent will enjoy a relatively high level of protection; that is, U.S. design patent registrations appear to be more difficult to invalidate.

\section{Copyright Approach}

German and French industrial design law, in particular, was initially based on the ideas and concepts of copyright law. ${ }^{98}$ Consequently, industrial designs were only protected against imitation - which meant that the claimant had to prove copying, that is, the infringer's knowledge of the specific industrial design. ${ }^{99}$

This was considered too serious an obstacle in enforcing design rights, which is why German design law in parte abandoned the 'copyright approach'. Right holders are notably granted relaxations of the burden of proof, including a presumption of validity of a registered design right (Section 39 German Designs Act), which makes litigation much easier. ${ }^{100}$ A recent ruling of the German Federal Supreme Court did further pioneering work in this respect. ${ }^{101}$

Traditionally, under German law, copyright protection had been granted for rather simple creations of works of fine, non-applied arts, such as music and literature. However, stricter standards had been applied in the case of works of applied arts (including industrial designs), and only very outstanding commercial performances obtained copyright protection. ${ }^{102}$

The Birthday Train decision changed this decades-old case law, concluding that such

\footnotetext{
96 www.wipo.int/wipolex/en/text.jsp?file_id=130047 (accessed 30 July 2020).

97 Lena Schickl, Protection of industrial design in the United States and in the EU: different concepts or different labels? [2013] The Journal of World Intellectual Property 15, 29.

98 See also Uma Suthersanen, Cross-border Copyright Protection in Europe (Chapter 15).

99 CHRISTOPHER MAIERHÖFER, Geschmacksmusterschutz und UWG-Leistungsschutz (Herbert Utz Verlag GmbH 2006) 10.

100 Ibid.

101 Birthday Train, German Federal Supreme Court, 13 November 2013, I ZR 143/12. For details see Uma Suthersanen, Cross-border Copyright Protection in Europe (Chapter 15).

102 For details see Henning Hartwig, Conflict, overlap or co-existence between design and copyright law? [2014] World Intellectual Property Review Annual 20.
} 
an obstructive discrimination of works of applied arts can no longer be maintained and no higher standards must be set in comparison with works of fine arts. Essentially, the Supreme Court found, first, that the new German design law of 2004, following the standards of the Designs Directive, established an independent IP right and severed any existing close relation to copyright law. Second, design law would not require a specific degree of creativity or originality; the focus would be on similarity or dissimilarity. Third, since design and copyright protection would not conflict but would instead co-exist, industrial design could be protected by both laws without requiring higher standards under copyright law than in the case of works of fine art, literature or music.

As a result, the Federal Court of Justice concluded that for the protection of works of applied art under copyright law, 'a degree of creativity which allows, from the view of a public open to art and sufficiently skilled in ideas of art, to be called an "artistic" performance' would be required, which is the traditional standard for works of fine art and literature. Consequently, differences in standards for protecting works of applied and non-applied arts no longer exist under German copyright law (interestingly, in the Birthday Train case no copyright protection was eventually granted, despite the more generous review standard).

The Birthday Train case law, to our knowledge, has not yet been confirmed or adopted by courts of other Member States (probably related to the fact that the various European Directives and other normative instruments do not contain specific provisions on works of applied art). Indeed, there are still significant differences between the copyright laws of the various Member States and those of other European countries. As a counterexample, there are similarities between German and Swiss law, ${ }^{103}$ as it is possible to establish both copyright and industrial design protection as far as the respective requirements are met ('parallel protection').

Interestingly, in Fisher Price v Davron, the Israeli Supreme Court (in a case related to the design for a rocking chair) found ${ }^{104}$ that where a product as such is eligible for design protection, it is not required to test whether the product as a whole is protected under copyright law because, pursuant to Article 7 Israeli Copyright Act, both rights are mutually exclusive. Consequently, a product can no longer enjoy parallel protection (provided a sufficient level of creativity is met). Overall, the Court, explicitly considering comparative law, ${ }^{105}$ subsequently established a three-tier analysis for the issue of first impression, that is, examining whether the article is eligible for design protection, whether it is possible to separate the original work from the article and whether the original work is eligible for copyright protection. ${ }^{106}$

103 Article 2 Swiss Copyright Act; Article 2 Swiss Designs Act; see also LuKas Mezger, Die Schutzschwelle für Werke der angewandten Kunst nach deutschem und europäischem Recht (Vandenhoeck \& Ruprecht 2017) 169.

104 CA 1248/15 (31 August 2017). Following the Court, these findings also apply after the new Design Law came into force, that is, after 7 August 2018.

105 Particularly, Star Athletica v Varsity Brands, 137 S. Ct. 1002 (2017); see, in this respect, Eleanor M. Lackman, Cartwheeling through copyright law: Star Athletica, L.L.C. v Varsity Brands, Inc. [2017] TMR (Vol. 107) 1251; FrancesCa Montalvo Witzburg, Protecting fashion: a comparative analysis of fashion design protection in the United States and the European Union [2017] TMR (Vol. 107) 1131.

106 See also Carlsberg v Som, Delhi High Court, 14 December 2018, CS (COMM) 690/2018, pursuant to which a claim for design infringement and for trade dress infringement (passing off) 


\section{Design Approach}

European design law had its beginnings in the early 1990s. The Max Planck Institute, one of the leading players in the development of European design law, concluded that both the patent approach and the copyright approach were unsuitable for design law due to the above-mentioned disadvantages. ${ }^{107}$

This led to the concept of the 'design approach' (referred to as the 'trade mark approach' by some sources ${ }^{108}$ ), which still forms the basis of European design law today. Consequently, the marketing function of the design and not the performance of the designer or product manufacturer have priority. ${ }^{109}$ As a result, it is not the performance of the designer that is primarily assessed, but rather the design as such. Thus, the main criterion of the substantive examination of the design is individual character, that is, sufficient distinction and departure from prior art. ${ }^{110}$

\section{THE INTERNATIONAL LEGAL ENVIRONMENT: PAST AND PRESENT}

\section{History of Origin}

\section{a) TRIPS Agreement}

Pursuant to Article 2 (1) TRIPS Agreement, Members shall comply with Articles 1 through 12 and Article 19 Paris Convention. Pursuant to Article 2 (2) TRIPS Agreement, nothing in Parts I to IV of this Agreement shall derogate from existing obligations that Members may have to each other under the Paris Convention. Pursuant to Article 25 (1)

can be combined in a single suit, overturning Mohan Lal v Sona Paint, Delhi High Court, 2013 (55) PTC 61 (Del) (FB); see, however, also Crocs v Aqualite, Delhi High Court, 18 February 2019, CS (COMM) 903/2018, pursuant to which a claim for trade dress infringement (passing off) that is solely based on the shape of footwear which is already registered as a design is not maintainable (para 46: 'the passing off pleaded in the complaint is by use by the defendants of what is registered by the plaintiff as a design'); see also Holland v S.P. Industries, Delhi High Court, 27 July 2017, CS (COMM) 1419/2016, finding that 'where a design of an article is prepared for the industrial production of an article, it is a design and registrable under the Designs Act and under Section 14 (c) Copyright Act so that the author of such design can claim copyright. However, since such a design is registrable under the Designs Act, and if such design has been used for production of articles by an industrial process for more than 50 times by the owner of the copyright, or, by any other person with his permission, then such person ceases to have copyright in such design' (para 22). Different, to that extent, Article 96 (2) CDR: 'A design protected by a Community design shall also be eligible for protection under the law of copyright of Member States as from the date on which the design was created or fixed in any form. The extent to which, and the conditions under which, such a protection is conferred, including the level of originality required, shall be determined by each Member State.'

107 MAIERHÖFER (n 99) 10.

108 See Celli/Staub (n 49) Article 1, para 24; Helmut Eichmann, Das europäische Geschmacksmusterrecht auf Abwegen? [1996] GRUR Int. 859, 861.

109 MAIERHÖFER (n 99) 11.

110 Celli/Staub (n 49) Article 1, para 24. 


\section{Research handbook on design law}

TRIPS Agreement, Members shall provide for the protection of independently created industrial designs that are new or original.

Pursuant to Article 26 (1) TRIPS Agreement, the

owner of a protected industrial design shall have the right to prevent third parties not having the owner's consent from making, selling or importing articles bearing or embodying a design which is a copy, or substantially a copy, of the protected design, when such acts are undertaken for commercial purposes.

\section{Pursuant to Article 26 (2) TRIPS Agreement,}

Members may provide limited exceptions to the protection of industrial designs, provided that such exceptions do not unreasonably conflict with the normal exploitation of protected industrial designs and do not unreasonably prejudice the legitimate interests of the owner of the protected design, taking account of the legitimate interests of third parties.

The duration of design protection available shall amount to at least ten years (Article 26 [3] TRIPS Agreement).

\section{b) Paris Convention}

Pursuant to Article 1 (2) Paris Convention, the "protection of industrial property has as its object patents, utility models, industrial designs, trade marks, service marks, trade names, indications of source or appellations of origin, and the repression of unfair competition'.

In addition, in accordance with Article 2 (1) Paris Convention,

nationals of any country of the Union shall, as regards the protection of industrial property, enjoy in all the other countries of the Union the advantages that their respective laws now grant, or may hereafter grant, to nationals; all without prejudice to the rights specially provided for by this Convention.

In addition, the Paris Convention contains provisions for design protection relating to claiming priority (Article 4), failure to work, importation of articles, grace periods for the payment of fees for the maintenance of rights (Article 5) and temporary protection at certain international exhibitions (Article 11).

\section{c) Geneva Act of the Hague Agreement}

The Hague Agreement was signed by a total of 61 Contracting Parties and totally revised most recently in Geneva in 1999 (Geneva Act). International registration makes it possible for the right holder to obtain national design protection through a single application in all of the desired Contracting Parties.

Each Contracting Party may refuse the application based on its national requirements for protection following a substantive examination (Article 12 [1] Geneva Act). ${ }^{111}$ If not refused, the 'international registration shall, from the date of the international registration, have at least the same effect in each designated Contracting Party as a regularly-filed application for the grant of protection of the industrial design under the law of that Contracting Party' (Article 14 [1] Geneva Act).

111 StUtZ/BeutLER/KÜNZI (n 4) 1213, para 329. 
The international registration shall be effected for an initial term of five years counted from the date of the international registration (Article 17 [1] Geneva Act) and may be renewed for additional five-year terms, in accordance with the prescribed procedure and subject to the payment of the prescribed fees (Article 17 [2] Geneva Act). Where the law of a designated Contracting Party provides for a duration of protection of more than 15 years for an industrial design for which protection has been granted under that law, the duration of protection shall, provided that the international registration is renewed, be the same as that provided for by the law of that Contracting Party (Article 17 [3] Geneva Act). ${ }^{112}$

\section{d) Locarno Agreement}

The Locarno Agreement Establishing an International Classification for Industrial Designs provides for a unitary international system of classification of industrial designs. The Agreement contains a classification scheme corresponding to the purpose and aesthetic appearance of a product extending to 32 classes and 219 subclasses.

To date, the Locarno Agreement has been adopted by 58 Contracting Parties. ${ }^{113}$ In accordance with Article 2 Locarno Agreement, the 'international classification shall be solely of an administrative character. Nevertheless, each country may attribute to it the legal scope which it considers appropriate.' It seems to follow from this starting point that according to some jurisdictions, the classification of the products in which the design is intended to be incorporated or to which it is intended to be applied 'shall not affect the scope of protection of the design as such' (Article 36 [6] CDR), ${ }^{114}$ while other countries do not allow such a scope of protection to extend across all 32 classes of the Locarno Agreement. ${ }^{115}$

\section{Status Quo}

\section{a) Harmonisation in terms of formalities}

WIPO's Standing Committee on the Law of Trademarks, Industrial Designs and Geographical Indications is currently working on the details of a global Design Law Treaty. The Treaty shall be an international agreement intended to simplify and harmonise formalities and proceedings before national and regional authorities. The current draft does not contain predefined standardised requirements, but rather a maximum set of requirements which can be applied by the authorities of the Contracting Parties. ${ }^{116}$

Interestingly, recently, the WIPO Digital Access Service ('DAS') ${ }^{117}$ - an electronic

\footnotetext{
112 For details see Robert Mirko Stutz, International Design Law Policies: Present and Future (Chapter 13).

113 See www.wipo.int/treaties/en/ShowResults.jsp?lang=en\&treaty_id=14 (accessed 30 July 2020).

114 Green Lane v PMS International (n 24), para 79.

115 For details see Robert Mirko Stutz, International Design Law Policies: Present and Future (Chapter 13).

116 For details see Robert Mirko Stutz, International Design Law Policies: Present and Future (Chapter 13).

117 See www.wipo.int/das/en/ (accessed 30 July 2020).
} 
system allowing priority documents and similar documents to be securely exchanged between participating IP offices, enabling applicants and offices to meet the requirements of the Paris Convention for certification in an electronic environment - has apparently attracted more attention, with IP offices from, for example, Australia, Israel, Japan, Norway and South Korea joining the DAS system. ${ }^{118}$

Finally, and most importantly, turning to drawings, there is unfortunately no such thing as international design patent drawing rules. Such a convention is missed even more when considering the importance of clear, consistent and coherent representations of the subject matter of a design application, which, when going international, is intended to serve as a basis for establishing monopolies well beyond the domestic practice.

By way of demonstration, Community design no. 4001915-0005 registered on behalf of Airbnb, Inc. (indication of product: 'Graphical user interfaces') as shown in Figure 1.5 displays a variety of four different types of broken lines, resulting in complicated questions regarding interpretation of what is claimed (priority: US 29/584645).

Another example that, if registered as a design, would generate interesting discussions

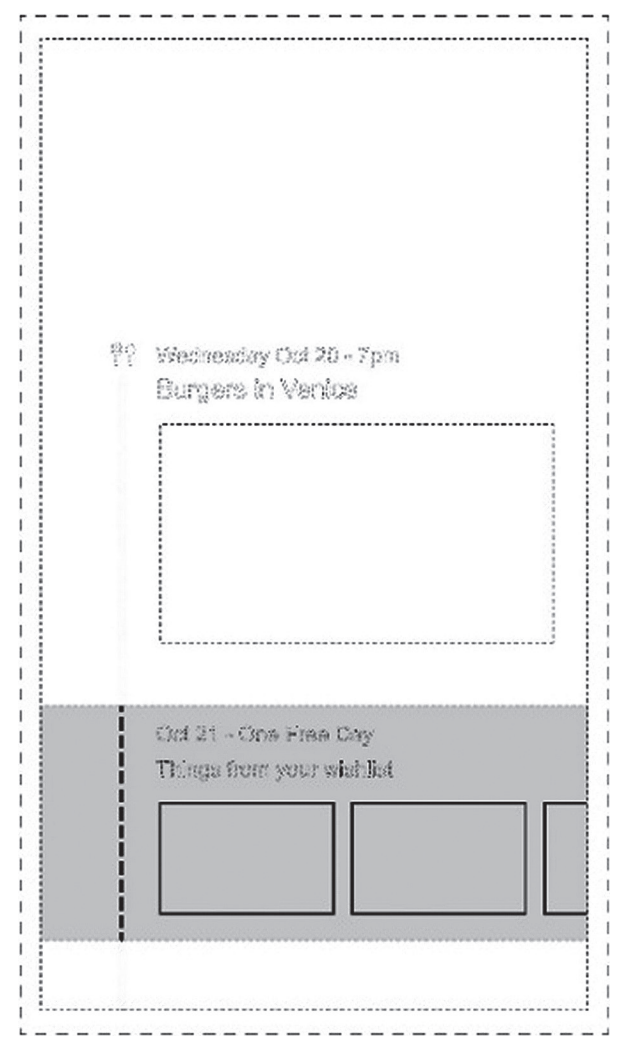

Figure 1.5 Community design registration no. 4001915-0005 (view 5.1)

118 See www.wipo.int/das/en/news/ (accessed 30 July 2020). 
on subject matter and scope (as there appears to be no connection between the three claimed portions) is U.S. trade mark no. 86913915 registered on behalf of Crocs, Inc. (goods: 'Footwear'), as shown in Figure 1.6:

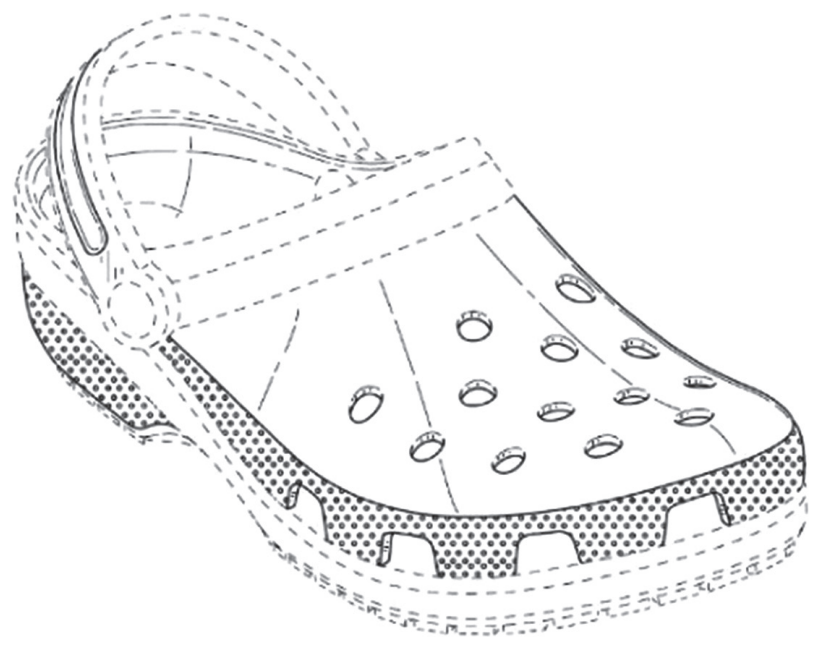

Figure 1.6 U.S. trademark registration no. 86913915 (fig. 1)

While some countries seem to have rules and guidelines that pertain specifically to drawings, ${ }^{119}$ the EUIPO Guidelines do not provide for any detailed convention beyond a broad definition of 'broken lines'. ${ }^{120}$ Also, under the European scheme, neither the CDR nor the CDIR provides rules for the understanding of visual disclaimers. The EUIPO Guidelines refer to the Common Practice (CP6) ${ }^{121}$ according to which 'visual disclaimers indicate that protection is not being sought and registration has not been granted for certain features of the design shown in the representation'. ${ }^{122}$ Also, it is common

119 E.g., USPTO, Manual of Patent Examining Procedure (https://www.uspto.gov/web/offices/ pac/mpep/s1503.html\#d0e151275; accessed 30 July 2020); USPTO, Design Patent Application Guide (www.uspto.gov/patents-getting-started/patent-basics/types-patent-applications/design-pat ent-application-guide\#surface; accessed 30 July 2020); IP Australia, Designs Examiners' Manual of Practice and Procedure (http://manuals.ipaustralia.gov.au/designs/designs_exam_manual.htm); also Intellectual Property Office of Singapore (www.ipos.gov.sg/docs/default-source/resourceslibrary/design/infopacks/acceptable_unacceptable-images---new-(latest-as-at-01072016---with-iposlogo.pdf; accessed 30 July 2020).

120 See EUIPO's Guidelines for Examination of Registered Community Designs (n 32), para 5.3.1: 'Broken lines consist of a trace made up of dots or dashes (or a combination of both) and are used to indicate that no protection is sought for the features shown using an interrupted trace.'

121 See Convergence on graphic representations of designs - Common Communication (status: 15 May 2018; https://euipo.europa.eu/tunnel-web/secure/webdav/guest/document_library/content Pdfs/about_euipo/who_we_are/common_communication/common_communication_7/common_ communication7_en.pdf; accessed 30 July 2020). See also AIPPI Summary Report, Study Question (Designs) Requirements for protection of designs (2016) 9 et seq. (https://aippi.soutron.net/Portal/ DownloadImageFile.ashx?objectId=4907; accessed 30 July 2020).

122 See EUIPO's Guidelines for Examination of Registered Community Designs (n 32), para 5.3. 
understanding that visual disclaimers may be shown by broken lines, blurring or colour shading. ${ }^{123}$

However, as demonstrated above, problems arise where claimed and disclaimed matter cannot be clearly differentiated; for instance, where broken lines are used to indicate stitching on clothing or patterns, or when the visual disclaimer is not shown consistently in all the views where the disclaimer appears. Also, the meaning of different kinds of 'broken lines' - dotted, dashed, dot-dashed, dot-dot-dashed - is unclear. In addition, and most importantly, the EUIPO's Guidelines do not bind applicants or higher authorities. ${ }^{124}$

That said, an agreement on an international convention of how to 'interpret' visual disclaimers to exclude features of a design from protection would and should be highly appreciated. ${ }^{125}$ As a starting point, the USPTO's Manual appears to be a rich source of guidance $^{126}$ (in comparison with other jurisdictions) and should be recommended to other law makers as a source of inspiration.

\section{b) Non-harmonisation in terms of substantive law}

It follows from the above that no further harmonisation of substantive design law is intended to be addressed for the time being. ${ }^{127}$ Particularly notable is that no so-called grace period, which would protect right holders against their own harmful prior art when disclosed within a certain period of time, ${ }^{128}$ exists under international design law. ${ }^{129}$

Another area that would seem to merit closer attention and international harmonisation

\section{Ibid.}

124 See EUIPO's Guidelines for Examination of Registered Community Designs (n 32), para 1.1: 'The purpose of the Guidelines is to ensure consistency among the decisions taken by the Operations Department and to ensure a coherent practice in file handling. These Guidelines are merely a set of consolidated rules setting out the line of conduct that the Office itself proposes to adopt, which means that, to the extent that those rules comply with the legal provisions of a higher authority, they constitute a self-imposed restriction on the Office, in that it must comply with the rules which it has itself laid down. However, these Guidelines cannot derogate from the CDR, the CDIR or the CDFR, and it is solely in the light of those regulations that the applicant's capacity to file an application to register a Community design must be assessed.'

125 See, to this extent, David Musker, Easier to See than to Say: Catching the Elusive Spirit of Design in a Net of Words (Chapter 3).

126 For further details, e.g., Murray H. Henderson, Patent Drawing Rules, 2nd ed. (Studio 94 Publishing 2016), 155 et seq.

127 For details see Robert Mirko Stutz, International Design Law Policies: Present and Future (Chapter 13).

128 See, for instance, Article 7 (2) CDR: 'A disclosure shall not be taken into consideration (. . .) if a design for which protection is claimed under a registered Community design has been made available to the public by the designer, his successor in title, or a third person as a result of information provided or action taken by the designer or his successor in title; and during the 12-month period preceding the date of filing of the application or, if a priority is claimed, the date of priority.'

129 Recently, Singapore (Division 8A [1] Singapore Registered Designs Act), South Korea (Article 36 [1] South Korean Design Protection Act) and Taiwan (Article 22 Taiwan Patent Act) extended the grace period for filing after public disclosure of the design from six months to one year. Israel introduced a grace period for registering a design when the new Designs Act no. 57772017 came into force on 7 August 2018; see Article 9 Israel Designs Act. Contrary to that, in Australia there is still no effective grace period to design registration applications; see, to this extent, K2 Office v Justin Peter Brown [2018] ADO 4 (29 October 2018). However, following a consultation in 2019, IP Australia supports introducing a grace period with a prior use defence (see https:// 
is the terra incognita of establishing appropriate standards for assessing disclosure of designs on the internet. This field of interest - which, with the rapid emergence of global, shoreless digitalisation, calls for immediate action - would not be limited to issues of validity, ${ }^{130}$ but would also encompass infringement and jurisdiction.

Lastly, in a more general sense, one may identify a global formal dichotomy between 'registration' and 'examination' systems. ${ }^{131}$ More particularly, a closer look seems to reveal that, by way of example, the description or title of a design is considered as a major formal and substantive requirement under various jurisdictions (both 'registration'132 and 'examination'133 systems) but, for instance, treated differently under EU law and practice. ${ }^{134}$ Overall, hence, it appears that the 'real' dichotomy in international design law exists between product-related and product-unrelated design protection. It seems fair to say that there will be no such thing as harmonised substantive international design law unless this basic dichotomy is overcome; currently, harmonisation clearly stops at the borders of both parts of this dichotomy.

consultation.ipaustralia.gov.au/policy/design-reforms-implement-acip-recs/user_uploads/2020-0508-ip_australia_response_to_public_consultation-2.pdf; accessed 30 July 2020).

${ }_{130}$ For instance, EUIPO, Criteria for assessing disclosure of designs on the Internet (Status: April 2020; https://euipo.europa.eu/tunnel-web/secure/webdav/guest/document_library/News/cp10/CP 10_en.pdf; accessed 30 July 2020); see also Henning HaRTwIG, Disclosure on the Internet under Community Design Law, in EUIPO (ed.), 20 years of the Boards of Appeal at EUIPO - Celebrating the Past, Looking Forward to the Future, Liber Amicorum (2017) 188 et seq.

131 Albeit this is no clear antipode as also 'fusion' systems exist (for instance, in Australia; see, e.g., TYrone Berger, Designing GUIs: current treatment of virtual or non-physical designs in Australia [2019] QMJIP 92), and 'registration' may include some formal 'examination', for instance under the Community design scheme.

132 E.g., China; for details see Tracy-Gene G. Durkin, Design Protection for Graphical User Interfaces (Chapter 11).

133 E.g., Curver Luxembourg v Home Expressions, 2018 WL 340036 (D.N.J. Jan. 8, 2018): "Curver then resubmitted the design patent as "[t]he ornamental design for a pattern for a chair." Each figure in the published patent is described as a view of a "design for a pattern for a chair." The title of the patent is a "Pattern for a Chair." The scope of the claim was thus narrowed during the prosecution history. Curver surrendered a claim for an ornamental pattern "for furniture" and accepted a design patent for an ornamental pattern "for a chair." This is just the sort of claim surrender that gives rise to prosecution history estoppel (...) the claim scope was surrendered in order to secure the patent - indeed, as a condition of obtaining the patent. The PTO, rejecting the initial, broader application, explained that Curver's patent must "designate the particular article" that is the subject of the design. A design patent extends to "an article of manufacture"; 35 U.S.C. $\S 171$ provides that "whoever invents any new, original and ornamental design for an article of manufacture may obtain a patent therefor, subject to the conditions and requirements of this title." Thus, by statute, a design patent is limited to one article of manufacture, and an inventor of an ornamental design may obtain a patent for that design for that article (...) The scope of a design patent is limited to the "article of manufacture" - i.e., the product - listed in the patent. Thus, the patent protects only a pattern for a chair. It does not protect that same pattern on a basket. That Curver manufactures a basket using the design only confuses the issue. Curver's claim must be that its patent was infringed; a basket, as such, cannot be infringed.'

134 For details see Henning Hartwig, Reciprocity in European Design Law (Chapter 4). 